\title{
Do Animals Go to Heaven? Medieval Philosophers Contemplate Heavenly Human Exceptionalism
}

\begin{abstract}
By Joyce E. Salisbury*
Beginning in about the second century C.E., Christian philosophers reflected upon the nature of human beings, our purpose on earth, and our path to the promised afterlife. In the course of these reflections, they considered our relationship to nature, and the nonhuman animals that share our world. Most thinkers accepted a Biblical mandate of 'mastery' to explain that humans should have dominance over animals, but that only described this world, not the next. Most theologians asserted that humans were exceptional because they had 'reason,' and most early Christians established a correlation between 'reason' and 'soul.' This meant that for them animals had no soul so there was no place for them in heaven.

The question of immortality might have remained unambiguously in the hands of humans if theologians believed that only our souls were immortal. As soon as theologians concluded that our flesh would join our souls in heavenly reward, the door was opened for animals to enter into paradise. For, after all, animals had bodies and flesh just as humans do. Some thinkers argued that just as human bodies will be transformed for salvation, animal bodies, too, can be redeemed and changed to enjoy an afterlife. For these theologians, God is prepared to save His whole creation - plants and animals -and we will all enjoy the next life.

This paper traces the various ideas about animals in heaven and suggests that these attitudes towards heaven reveal what we think about animals, humans, and the web of life.
\end{abstract}

In the fourth century, the Roman Empire became a Christian empire, and for the first time, thinkers considered the span of a human life to extend beyond death. During the pagan years, most people considered the afterlife a vague shadowy place, best ignored, and dead bodies were thought to be polluting, and best buried outside the walls of the city. With the coming of Christianity, however, the faithful came to hope for a Resurrection that defeated death and extended their life somewhere else and somewhere glorious. The remains of the Christian dead seemed no longer polluting, and cemeteries moved within the walls (or often people moved to be closer to the burial spaces) as people wanted to be close to the holy remains of the dead who were perhaps already

${ }^{*}$ Professor Emerita History, University of Wisconsin - Green Bay, USA 
participating in the expected afterlife. These attitudes toward death changed the geography of both Christian cities and human minds as people began to consider what heaven might look like. And these reflections included considerations of animals that shared this world. Would they also share the next one?

The question of whether animals could share heaven depended on people's beliefs on two subjects: 1) the nature of the resurrected body, and the look of heaven itself. To explore the resurrected bodies, Christians began with the Greek thinkers that were so influential on their views. The ancient Greeks and Plato believed the soul was immortal, that it had existed before it had entered the mortal body, and would continue to exist when the flesh had fallen away. If the soul was the only immortal part that was promised resurrection, then animals were excluded. Early Christian thinkers believed that animals had no souls because souls were linked to the rational part of humans - the mind and the reasoning self.

Augustine in the late fourth century confidently asserted that humans were superior to animals because humans were 'rational creatures,' not 'brute animals,'(Augustine, 1948) and he was only the first of many Christian thinkers to express this perspective. Human reason came from a divinely sparked intellect and without this there could be no afterlife. Thomas Aquinas in his $13^{\text {th }}$ century synthesis of Christian knowledge said that animals are 'without intellect,' and thus they were 'not made in God's image.' The promise of Jesus's resurrection claimed that only those beings who were in God's image would escape death, and for the early Christians and medieval philosophers, God's image meant thinking like a human.

Medieval analysts sometimes had to work hard to preserve the notion that animals lacked 'reason.' When philosophers observed complex behavior in animals, they search for explanations that required only instinct, not rational thought. For example, a much-discussed instance was why a sheep ran from a wolf. There was nothing obviously hazardous in the appearance of the wolf (that is, in its color, furriness, four-leggedness, etc.) yet a sheep ran in its presence. Medieval thinkers solved this dilemma by positing a sixth sense, called estimativa, that could perceive intentionality. Philosophers kept adding internal senses to avoid granting animals the possibility of rational thought, and by the $12^{\text {th }}$ century, Avicenna argued for an additional five to explain the vagaries of observed instinctive behavior in animals. These efforts were intended to keep animals from sharing what philosophers perceived as the defining human quality of logical reasoning, and this quality was what defined soul and which was the entry ticket to heaven. Human exceptionalism and heaven itself rested on the capacity for logical reasoning.

This relationship between a perceived human soul and rationality has pervaded various aspects of animal rights beyond the question of animals in heaven. For example, Richard Sorabji points out that at times people believed that the human soul was immortal because it was rational (not vice versa), and that other animals might have a soul, but if they were irrational, they are excluded from considerations of human justice, and heaven itself. 
(Sorabji,1993). This loophole has allowed theologians who might think that any living being has a soul by virtue of its life to exclude irrational souls from heaven. This idea is problematic because it doesn't allow for infants or the insane, both considered irrational, to go to heaven. Therefore, for most Christian thinkers it was easiest to simply deny that animals had souls.

Excluding animals from a heaven inhabited only by immortal human souls was fairly unambiguous. However, in the formative years of Christian theology, most Christians believed that there was more to heaven than a place for immortal souls to return. Questions of justice and personal identity really called forth a resurrection of a body, a body that had lived in this world and acquired a history of deeds that had created a full person worthy of being judged. Paul claimed that the resurrected bodies would be substantially different from our earthly ones: 'What [body] is sown is perishable, what is raised is imperishable. . . . It is sown a physical body, it is raised a spiritual body.' (1 Cor. 15:35, 42-44). He concludes by saying 'I tell you this, brethren: flesh and blood cannot inherit the kingdom of God, nor does the perishable inherit the imperishable' (1 Cor. 15:50).

Paul's view of resurrected bodies did not necessarily preclude the idea of animals in heaven, for theoretically an animal could acquire a transformed body for heaven just like humans could. For example a transformed vegetarian lion might lie down with a fearless lamb. However, the apostle did say that that human flesh is different from animal flesh: 'For not all flesh is alike, but there is one kind for men, another for animals, another for birds, and another for fish.' He used this contrast to explain the similar difference between 'celestial bodies and terrestrial bodies.' (1 Cor 15:35.) This difference leaves open the possibility that animal flesh, too, might be transformed for resurrection.

The third-century controversial church father, Origen, offered an explanation of transformed bodies that seemed to reconcile the Platonist notion of immortal soul with Paul's idea of a spiritual body. The earthly body offered an immortal soul a vehicle through which to express its free will and earn salvation. The immortal soul was then linked to the transformed body throughout eternity. (Origin, 1995).

Many ancient writers tried to describe these transformed bodies with their souls, and most envisioned what we imagine as ghosts - spirits who visually resemble the bodies they once inhabited but who are not bound by the physical realities of this world that bind our bodies. If the fourth-century Cyril of Jerusalem is right, we will shimmer with self-contained light in the dark of the universe, 'like glowworms on a summer night'(Salisbury, 2004).

Since all these early fathers were certain that animals did not possess souls, through this definition, they were excluded from the resurrection since their bodies could not be transformed by their souls. Resurrected animal flesh might be transformed, but without an animal soul to animate it, animals could not share an afterlife.

In the fourth century, the experience of Christians who observed the tortured flesh of martyrs led to a different view of the resurrection. Justice seemed to require that the very flesh that had suffered so on this earth should 
be rewarded in the next, and this meant that the transformed, ghostly bodies envisioned by Paul were not sufficient. The fourth-century irascible church father, Jerome, said 'flesh has one definition and body another'(Bynum, 1995). Those who advocated this view - that became the predominant one in Catholic theology - claims that this very flesh would be resurrected on judgment day.

Tertullian, in the late second century, articulated the fullest explanation of the resurrection of the flesh. Tertullian joined earlier thinkers like Paul in acknowledging the existence of a mortal soul, but he argued that during life, the soul takes on many characteristics as the body, for it 'spread itself throughout the spaces of the body and impressed itself on each internal feature. Hence there arose a fixing of the soul's corporeity.'(Tertullian, 1995) The soul then grows and changes with the body's growth taking on the identity of the body that imprinted it. Thus, for Tertullian, the soul very much resembled the transformed bodies of Paul and Origen, but there were no animal souls waiting for their flesh to return. If Origen and Tertullian saw the same ghost, the first would identify it as the resurrected saved body, and Tertullian would claim it was the corporeal soul that was waiting sadly to rejoin the resurrected flesh.

Once Christians came to focus on the flesh itself as the immortal vehicle for heaven, they immediately had to confront the animals of this world. Life and growth required people to eat, and most ate animals. Scholastics of the thirteenth century wrestled with this problem as they considered resurrected flesh, wondering if such flesh represented cows and sheep in heaven. Not surprisingly, they decided that the imprint of the human soul was sufficient to miraculously transform the animal meat into real human flesh so that humans, not the animals they ate, populated heaven (Bynum, 1995). Some writers have suggested that this is the way animals get to heaven - by being converted, that is perfected, into human flesh. This is human exceptionalism taken to an extreme.

Death, too, marked a point of intersection between the human body and its animal counterpart. Augustine wrote, 'All men born of the flesh, are they not also worms?' (Augustine, 1884). In the end, if the body had not been eaten by beasts, fish, or birds, then worms consumed this flesh that had been promised to enjoy paradise. On resurrection day, how were these consumed bits of human flesh - that as they had been eaten by animals became animal flesh supposed to be reassembled in order for the saved humans to be given back their original flesh, leaving the animals behind?

Animals, too, had to be resurrected so they could return the human flesh they had eaten. The cathedral at Torcello, near Venice, has an eleventh-century mosaic that shows animals and fish resurrected on the last day and dutifully vomiting up the human body parts they had eaten in their lives. In this incident, we can see that the theology of the resurrection of the flesh opened the way for animal flesh, too, to be resurrected. Then the question became where do the animals go after they were resurrected? The answer to that depended upon what heaven might look like. In this, too, Christians had a difference of opinion. 
The first question that plagued thinkers was what animals would do in heaven. Medieval thinkers did not believe animals had any purpose independent of their service to humans. Thus, animals served as food, clothing, and labor for their human masters. Aquinas decided that since humans in heaven would need not clothing, food, nor would they work, there was no need for animals in heaven, so they were excluded (Aquinas, 1952). For medieval thinkers, for animals to exist in any other capacity in heaven, depended on their vision of what heaven might look like. Was it an animal-free city or a garden that might have animals?

Many of the early Christians saw heaven as a great and beautiful city. The 'Book of Revelation' in the Bible saw a heavenly city that awaited the end of the world, and Augustine most famously saw the City of God as an ideal Platonic form of a perfect city that awaited the faithful. Other visionaries who claimed to see heaven also echoed this view. For example, a fourth-century text, called 'St Peter's Apocalypse' describes a 'City of Christ. It was all gold, and twelve walls encircled it, and there were twelve towers inside' (Gardiner, 1989). If heaven was a city, there was no question about the presence of animals - they weren't there.

Things became more complicated in visions of heaven as a garden; a perfected return to the garden of Eden. The second-century Apocalypse of St. Peter described a heaven full of flowers, and a 'great garden, open, full of fair trees and blessed fruits, and of the odor of perfumes'(Gardiner, 1989). The influential third-century account of the martyr Perpetua's dream of heaven added additional details to the heavenly garden; 'I saw an immense garden, and in it a grey-haired man sat in shepherd's garb; tall he was, and milking sheep. . .. he gave me a mouthful of the milk he was drawing. . .'(Salisbury, 1997). Here, we have the presence of an animal in heaven.

Heavenly gardens presume the existence of food, decay, and animals. By the fourth century, some people certainly believed that animals would be resurrected on the final days, whether it was to return the body parts they had eaten, or to go to Hell to eat the resurrected bodies of the damned, or to join the saved in a garden of paradise. A second-century bishop, Papias, described an extraordinary vision of a heavenly garden, in which plants - like grapes and grain - would bear miraculous yields, and 'all animals, feeding on these products of the earth, will become peaceable and friendly to each other, and be completely subject to man'(Bynum, 1995).

Here we can see a distinct split between the prevailing intellectual view of animals - no soul, no heaven -- and a more ambiguous popular view that could not really imagine a heaven that lacked the pleasures of this world, whether a sweet, fragrant fruit tree, or tame animals. In the fifteenth century, we see some famous people burying their beloved pets with hope for the afterlife. For example, one epitaph on the headstone of a little dog named Viola insists that the dog now resides in heaven. One courtier wrote an elegy for the wealthy Isabelle d'Este's dog, Aura, describing 'the playful Aura's ascent to heaven,' though Aura's heaven was the stars, where she could join the 'dog star'(Walker-Meikle, 2012). How could these ideas be reconciled? 
Christians who wanted to see their animals in heaven could look to biblical precedent. In the Psalms the poet claims 'Man and beast thou savest, O Lord' (Psalm 36:6b), and the New Testament in the letters of Paul, promises that the whole earth will be saved, and Christ would 'unite all things in Him, things in heaven and things on earth' (Ephesians 1:9-10) (Linzey \& Regan,1990; Linzey \& Yamamoto, 1998). Once theologians believed that the flesh itself would have eternal life, the way was opened for animal flesh, too, to join humans in the afterlife. The problem remained to consider exactly how this would work. Animals still didn't have souls and animals had no reason - no self-identity so what exactly would be resurrected?

Most people who today think about animals in heaven consider their beloved pets, like Isabella d'Este's Aura. C.S. Lewis offered an explanation that provided a path for pets to get into heaven while leaving less desirable creatures - tapeworms and mosquitoes - behind. He suggested that pets are transformed by their encounter with humans, they are given personality and individuality, which would extend into the next life. As he wrote, 'in this way it seems to me possible that certain animals may have an immortality, not in themselves, but in the immortality of their masters'(Linzey \& Regan, 1990). This preserves the striking anthropocentric view that kept animals out of heaven in the first place. Animals have no independent value in this world and no access to the next unless good pets can slide in on the coattails of their masters.

This was not the end of the story. Remarkably, there was a less anthropocentric vision that stayed on the margins of medieval thought. Some people saw God's creation as a unity, a great web in which all are linked together in this world, and transformed into the next. In this view, the question is not whether animals would go to heaven, but whether a whole environmental web of creation might be risen to an afterlife. As St. Irenaeus wrote, on the last day, Jesus would 'sum up all things in Himself' (Linzey \& Regan, 1990). Susan Crane (2013), in her recent book, Animal Encounters analyzes medieval texts that show this kind of interconnectedness. She sees Irish hagiographers who see the world horizontally, in which all are 'intricately enmeshed in dynamic environments stretching outward and upward beyond our ken' (Crane, 2013). She even sees connections within the bestiaries, those texts that organize the animal world in ways that make sense to humans. Here, animals and humans are joined in a web of creation that links creature to creature (Crane, 2013). In this vision, heaven is a perfected earth, recreating the biblical vision in which 'The wolf shall dwell with the lamb, and the leopard shall lie down with the kid, and the calf and the lion and the fatling together, and a little child shall lead them.' All will be vegetarians, for the lion will 'eat straw like the ox,' and children will play with previously poisonous snakes. (Isaiah 11:68) Presumably, in this blissful paradise, even vegetarian bedbugs will sleep in harmony with humans.

While it is not directly within the scope of my paper on medieval ideas, I would like to mention that some modern theologians who believe animals will share our afterlife build on this web-like connection of life to suggest that the 
whole complex web will enjoy an afterlife. Thus our bodies that include over three pounds of bacteria will go intact to the next life along with the full environmental world of which we are so integral a part. This position - like the views of the past - owes more to a modern vision of environmentalism to any privileged knowledge of heaven. Of course, that's what all our visions of paradise are about.

Medieval thinkers - like modern ones -- had a whole range of visions of the afterlife from a purely anthropocentric view to a more integrated view in which all of creation was perfected into the next world. Why should we care about these options? Human visions of heaven mark our highest hopes, and inevitably these hopes affect how we act in this world. In a purely anthropocentric vision, the environment is temporary and animals are irrelevant. However, people who truly believe that we are all in this together and we will all share in the reward of heaven might look and act more generously to the world that surrounds us. The lion might not lie down with the lamb in this life, but there are ways to live more harmoniously together. That is a decent aspiration.

\section{Bibliography}

Aquinas, T. (1952). On the Power of God.Westminster, MD: Newman Press.

Aquinas, T. (1947). Summa Theologica. Trans. English Dominican Fathers. New York: Benzigen Bros.

Augustine (1948). "Divine Providence and the Problem of Evil," trans. R.P. Russell. In Writings of Saint Augustine, vol 1. New York: Fathers of the Church, Inc.

Augustine, (1884). 'In Joannis Evangelium tractatus,' In: J. Migne (ed). Patrologiciae Cursus Completus, Series Latina v. 35, 1385.Turnhout.

Crane, S. (2013). Animal Encounters: Contacts and Concepts in Medieval Britain. Philadelphia: University of Pennsylvania Press.

Linzey, A. \& T. Regan (eds.). (1990). Animals and Christianity. New York: Crossroad Publishing.

Linzey, A. \& D. Yamamoto, (eds.). (1998). Animals on the Agenda. Chicago: University of Illinois Press.

Salisbury, J.E. (2011) The Beast Within: Animals in the Middle Ages, $2^{\text {nd }}$ ed.. New York: Routledge.

Salisbury, J.E. (2004). The Blood of Martyrs: Unintended Consequences of Ancient Violence. New York: Routledge

Salisbury, J.E. (1997) Perpetua's Passion: Death and Memory of a Young Roman Woman. New York Routledge.

Sorabji, R. (1993). Animal Minds \& Human Morals: The Origins of the Western Debate. Ithaca: Cornell University Press.

Walker-Meikle, K. (2012). Medieval Pets. Woodbridge: Boydell Press. 
